\title{
Hematopoietic stem cell transplantation with latently infected donors does not transmit virus to immunocompromised recipients in the murine model of cytomegalovirus infection
}

\author{
Christof K. Seckert • Angélique Renzaho • \\ Matthias J. Reddehase • Natascha K. A. Grzimek
}

Received: 3 March 2008 / Published online: 26 March 2008

(C) Springer-Verlag 2008

\begin{abstract}
Hematopoietic stem cell transplantation (HSCT) bears a risk of reactivating latent cytomegalovirus (CMV) in either the transplanted hematopoietic donor cells or in parenchymal and stromal tissue cells of the immunocompromised recipient, or in both. While reactivated human CMV in recipients of organ transplantations is frequently the virus variant of the donor, this is not usually the case in HSCT recipients. Here we have used experimental sex-mismatched HSCT in the BALB/c mouse model to test if latent murine CMV from CMV-immune donors is transmitted with bone marrow cells to naive immunocompromised recipients.
\end{abstract}

Keywords Bone marrow - Chimerism - Cytomegalovirus . Hematopoiesis · Hematopoietic stem cell transplantation (HSCT) - Latency · Latent infection · Quantitative PCR . Recurrent infection $\cdot$ Stromal cells $\cdot$ Reactivation $\cdot$ Sexmismatched HSCT $\cdot t d y$ gene

\section{Introduction and clinical background}

Allogeneic hematopoietic stem cell transplantation (alloHSCT) is a therapeutic option against forms of leukemias that are not eradicated by conventional antitumoral therapies $[1,2]$ (see also the contribution by Erlach et al. in this issue of MMI). In the gap period of an immunocompromised state between hematoablative treatment and complete lympho-

C. K. Seckert · A. Renzaho $\cdot$ M. J. Reddehase $\cdot$

N. K. A. Grzimek ( $\square)$

Institute for Virology, Johannes Gutenberg-University,

Obere Zahlbacher Strasse 67, Hochhaus am Augustusplatz,

55131 Mainz, Germany

e-mail: grzimek@uni-mainz.de hematopoietic reconstitution-including the reconstitution of mature CD4 and CD8 T cells-HSCT recipients are at risk of reactivating latent cytomegalovirus (CMV) with the consequence of recurrent productive infection and manifestations of CMV disease, of interstitial pneumonia in particular $[3,4]$ (see also the contribution by Ho in this issue of $\mathrm{MMI}$ ). Obviously, there is no risk if both donor and recipient have never experienced CMV (donor-recipient status $\mathrm{D}^{-} \mathrm{R}^{-}$), as they do not harbor latent virus. In the combinations $\mathrm{D}^{+} \mathrm{R}^{-}, \mathrm{D}^{-} \mathrm{R}^{+}$and $\mathrm{D}^{+} \mathrm{R}^{+}$(in clinical practice usually assessed from the serostatus with regard to the presence of CMV-specific antibodies) latent CMV can reactivate from the transplanted donor cells, from the recipient's own latently infected tissue cells, and from both, respectively (for a review see [5]).

In the case of HSCT, a risk of CMV reactivation in the combination $\mathrm{D}^{+} \mathrm{R}^{-}$implies that CMV latency is established in cells of hematopoietic differentiation lineages, that is in stem cells, progenitor cells or the more mature progeny thereof. For latent human CMV (hCMV) infection there indeed exists a large body of evidence to conclude that a low proportion of $\mathrm{CD} 34^{+}$myeloid lineage early progenitor cells and their lineage-committed descendants, dendritic cell progenitors in particular, can be latently infected. They carry latent viral genome as an episome in a higher order chromatin-like structure, can express a limited set of "latency-associated" transcripts, and can reactivate infectious virus upon cell differentiation or certain stimuli thought to involve chromatin remodeling for desilencing of productive cycle genes [6-15] (for reviews see [16-20]). An important aspect to be taken into account is the significant genetic and phenotypic variance between recent clinical isolates or strains of hCMV [15, 21, 22]. Studying 20 recent clinical isolates in long-term bone marrow cell cultures, the group of Beverly Torok-Storb found only eight 
myelotropic isolates infecting hematopoietic cells of the myeloid lineage, four of which failed to infect the bone marrow stromal cells [21]. More recently, work by Goodrum and colleagues from the laboratory of Thomas Shenk showed that only low-passage strains of hCMV were able to infect $\mathrm{CD} 34^{+}$myeloid cells with the hallmarks of latency, whereas laboratory strains infected these cells productively. They provided evidence to conclude that UL138, which is present in the genomes of low-passage strains but is lost in high-passage laboratory strains, is required for hCMV to establish and/or maintain a latent infection in hematopoietic progenitor cells [15].

Thus, though with possible virus strain differences, latent donor virus could be transmitted by HSCT to immunocompromised recipients, reactivate, and cause CMV disease as well as establish latency in recipients' tissues after lymphohematopoietic reconstitution has resolved the acute infection. What these studies do not tell us is how efficient virus actually reactivates from latently infected hematopoietic progenitor cells, that is, how high the risk of CMV infection actually is in a $\mathrm{D}^{+} \mathrm{R}^{-}$combination of HSCT.

A very informative statistical survey of the risk associated with the serostatus for hCMV at time of transplantation, reported by Emery [23], revealed a distinctive difference between solid organ transplantation and bone marrow transplantation (BMT). In renal and liver transplant recipients, reactivating virus was found to be mostly donorderived [24] with a risk of symptomatic infection of the recipients ranking as $\mathrm{D}^{+} \mathrm{R}^{-}>\mathrm{D}^{+} \mathrm{R}^{+}>\mathrm{D}^{-} \mathrm{R}^{+}$. This clearly indicates that kidney and liver are organ sites of latent hCMV infection and that reactivation of virus from these sites is frequent and clinically relevant. In contrast, in bone marrow transplantation, the risk ranking was reversed to $\mathrm{D}^{-} \mathrm{R}^{+}>\mathrm{D}^{+} \mathrm{R}^{+}>\mathrm{D}^{+} \mathrm{R}^{-}$. Accordingly, reactivating virus was found to be mostly recipient-derived, which implies that it also originated from organ sites of virus latency. Transfer of donor immunity in the BMT setting could possibly explain the lower risk that is associated with CMV-immune donors, and we certainly also have to consider a role for differences in the clinical protocols used for solid organ and bone marrow transplantation. All these data are also compatible, however, with the hypothesis that latent hCMV reactivates from hematopoietic cells only inefficiently, and that parenchymal or stromal cells in host tissues are the more relevant reservoir for latent virus in both the organ transplant donor and the bone marrow transplant recipient.

Conscious of the fact that the murine model of CMV latency (for reviews see [25-28]) can never comprehensively reflect the phenotypic variance of all clinical isolates of hCMV, which laboratory strains of hCMV cannot either, we were interested in the basic question if latent murine CMV (mCMV) can be transmitted by experimental HSCT to highly susceptible, immunocompromised and CMV-naive recipients.

\section{Materials and methods}

Experimental HSCT and establishment of latent mCMV infection

Sex-mismatched allo-HSCT was performed essentially as described previously [29-31]. Recipients were female (XX, $t d y$ gene-negative) BALB/c mice ( $H-2^{d}$ haplotype). For serial HSCT, donors were male (XY, tdy gene-positive) $\mathrm{BALB} / \mathrm{c}$ mice in HSCT-1 or thus generated $\mathrm{XY}-\mathrm{XX}$ bone marrow chimeras in HSCT-2, resulting in XY-XX-XX trimeras. In brief, hematoablative conditioning of 8-10-weekold primary recipients was achieved by total-body $\gamma$-irradiation with a single dose of 6.5 Gy. HSCT-1 was performed $6 \mathrm{~h}$ later by infusion of $5 \times 10^{6}$ femoral and tibial donor bone marrow cells (BMC) into the tail vein of the primary recipients. After acute infection and establishment of latency, these chimeric primary recipients served as donors for HSCT-2. After the hematoablative conditioning of the secondary recipients, $90 \%$ of the total yield of BMC from one latently infected donor (two femurs and two tibias) was transplanted to one recipient (one-into-one HSCT), five donor-recipient pairs altogether. Infection of HSCT-1 recipients with $10^{5}$ plaque-forming units (PFU) of purified wild-type mCMV, strain Smith ATCC VR-194 (mCMVWT.Smith), was performed subcutaneously in the left hind footpad. The criteria for the definition of latency were specified previously (for a review see [25]) and include the absence of infectivity in key organs of CMV tropism (spleen, lungs, and salivary glands) as well as PCR-verified absence of viral DNA from blood $\left(<1\right.$ copy per $10^{4}$ leukocytes), which otherwise could contaminate bone marrow with intravascular cells. Clearance of viral DNA from blood is the criterion that takes longest to be fulfilled in the HSCT model, usually 8-10 months [25]. Animals were bred and housed under specified pathogen-free conditions in the Central Laboratory Animal Facility (CLAF) of the Johannes Gutenberg University. Animal experiments were approved according to German federal law under permission number 177-07/021-28.

Isolation of DNA from organs, bone marrow, and blood

A maximum of $25 \mathrm{mg}$ of tissue from lungs and liver and of $10 \mathrm{mg}$ from the spleen were homogenized with a QIAGEN Mixer Mill MM300 and a steel ball $(0.118$ in.) at $30 \mathrm{~Hz}$ for $3 \mathrm{~min}$. The homogenized tissue was pelletized, and DNA was extracted with the DNeasy Blood \& Tissue Kit (catalog. no. 69504; QIAGEN) as described previously [32], except that elution of DNA was in one round with a total of $200 \mu \mathrm{l}$ elution buffer. For isolation of DNA from bone marrow, $10 \%$ of the isolated BMC (a maximum of $5 \times 10^{6}$ cells per preparation vial) were resuspended in $200 \mu \mathrm{PBS}$ 
and lysed by proteinase $\mathrm{K}$ digestion, followed by DNA binding to the DNeasy mini column, washing steps, and one round of DNA elution in a total volume of $200 \mu$ l. For isolation of DNA from blood samples, $50 \mu \mathrm{l}$ of whole blood was immediately mixed with $20 \mu \mathrm{l}$ of EDTA ( $86 \mathrm{mM}$ stock solution in distilled water) and $130 \mu \mathrm{l}$ of phosphate buffered saline to reach a final volume of $200 \mu \mathrm{l}$. DNA was extracted using a QIAamp DNA Blood Mini Kit (catalog. no. 51106; QIAGEN) following the manufacturer's recommendations. In brief, protease digestion was followed by DNA binding to the QIAamp spin column, two rounds of washing, and elution of DNA in a total volume of $100 \mu \mathrm{l}$.

Quantitation of latent viral genomes and of male hematopoietic cells

In DNA from blood, only latent viral genomes were quantitated, whereas latent viral genomes and male sex-defining gene $t d y$ were quantitated in DNA from lungs, liver, spleen, and bone marrow by the respective real-time PCRs using the 7500 Real Time PCR System (Applied Biosystems) and the QuantiTect SYBR Green PCR Kit (catalog. no. 204143; QIAGEN). A 1/50 aliquot of each DNA preparation from organs or bone marrow and a 1/25 aliquot of the DNA preparation from blood was added as template DNA to a reaction mixture that included the QuantiTect SYBR Green PCR master mix with an initial $\mathrm{MgCl}_{2}$ concentration of $2.5 \mathrm{mM}$ and $0.75 \mu \mathrm{M}$ of each primer. Primers for amplification of a 135-bp fragment of the viral gene M55 $(\mathrm{gB})$ were LCgBforw and LCgB-rev, and primers for amplification of a 142-bp fragment of the cellular pthrp gene were LCPTHrPforw and LCPTHrP-rev, as described in greater detail previously [32]. For amplification of the 133-bp fragment of the Y-chromosomal $t d y$ gene, primers LCTdy-forw (5'-ATG CATTTATGGTGTGGTCCC-3') and LCTdy-rev (5'-AAG GGCCTTTTTTCGGCTTC- $3^{\prime}$ ), representing map positions 126-146 and 258-239, respectively, were used (GenBank accession no. 287804). PCR was performed with cycler conditions as described previously [32]. Standard curves for quantitation were established by using graded numbers of linearized plasmid pDrive_gB_PTHrP_Tdy [32] as the template.

\section{Results}

Experimental regimen of serial HSCT to evaluate transfer of latency with hematopoietic cells

The concept of serial HSCT is sketched in Fig. 1. In HSCT1, MHC-matched sex-mismatched allo-HSCT is performed by using BALB/c $\left(H-2^{d}\right)$ male BMC donors and female HSCT recipients, thus generating $\mathrm{XY}-\mathrm{XX}$ bone marrow chimeras characterized by a male hematopoietic compartment and a female stromal compartment. Prior to the transplantation, the recipients were immunocompromised by hematoablative conditioning, and shortly after the transplantation they were infected with mCMV-WT.Smith. The clinical correlate of HSCT-1 is a $\mathrm{D}^{-} \mathrm{R}^{-}$condition of HSCT (see "Introduction and clinical background") with an extraneous primary infection of the immunocompromised recipients.

Viral pathogenesis, lympho-hematopoietic reconstitution, resolution of the productive infection, and the establisment of latency in HSCT recipients have been analyzed in this model in great detail previously [29, 30, 33-37] (for reviews see $[25,27,28,38]$ and the contribution by Erlach et al. in this issue of MMI). Importantly, whereas under conditions of low-dose HSCT mCMV-WT.Smith inhibits the engraftment of hematopoietic donor stem and progenitor cells in the recipients' bone marrow stroma with the outcome of a lethal bone marrow aplasia [29, 30, 33], this pathogenesis is prevented under conditions of high-dose HSCT by the successful reconstitution of protective CD8 T cells $[34,35]$ with the result that acute infection is cleared and viral latency established [36, 37]. High-dose HSCT was therefore chosen here to establish a latent infection in the chimeric primary recipients for answering the specific question if viral latency is established in their bone marrow and if latent virus can be transmitted with hematopoietic cells to secondary HSCT recipients.

Consequently, HSCT-2 is performed using the latently infected HSCT-1 recipients now as donors. The clinical correlate of HSCT-2 is a $\mathrm{D}^{+} \mathrm{R}^{-}$condition of HSCT (see "Introduction and clinical background"). Since the recipients are naive in terms of CMV-experience and are severely immunocompromised, they lack CMV-specific antibodies and depend on donor hematopoiesis for mounting a protective adaptive immune response. In the vulnerable phase between hematoablative treatment and donor-derived hematopoietic reconstitution, such recipients are highly susceptible to a primary mCMV infection. We know that after intravenous administration a single infectious unit, that is $1 \mathrm{PFU}$, can initiate productive infection with the expected Poisson statistics and that 10 PFU infect all recipients. Thus, traces of residual infectious virus in the donor BMC as well as virus reactivation from latency in hematopoietic donor cells should be detected in this system with highest possible sensitivity.

Very low viral genome load in the bone marrow of latently infected HSCT-1 recipients

As discussed above, traces of infectious virus can lead to productive infection in immunocompromised recipients. Thus, for testing transfer of viral latency and a true post-transplantational recurrence in HSCT-2 recipients, it was a mandatory precondition to rigorously exclude a 


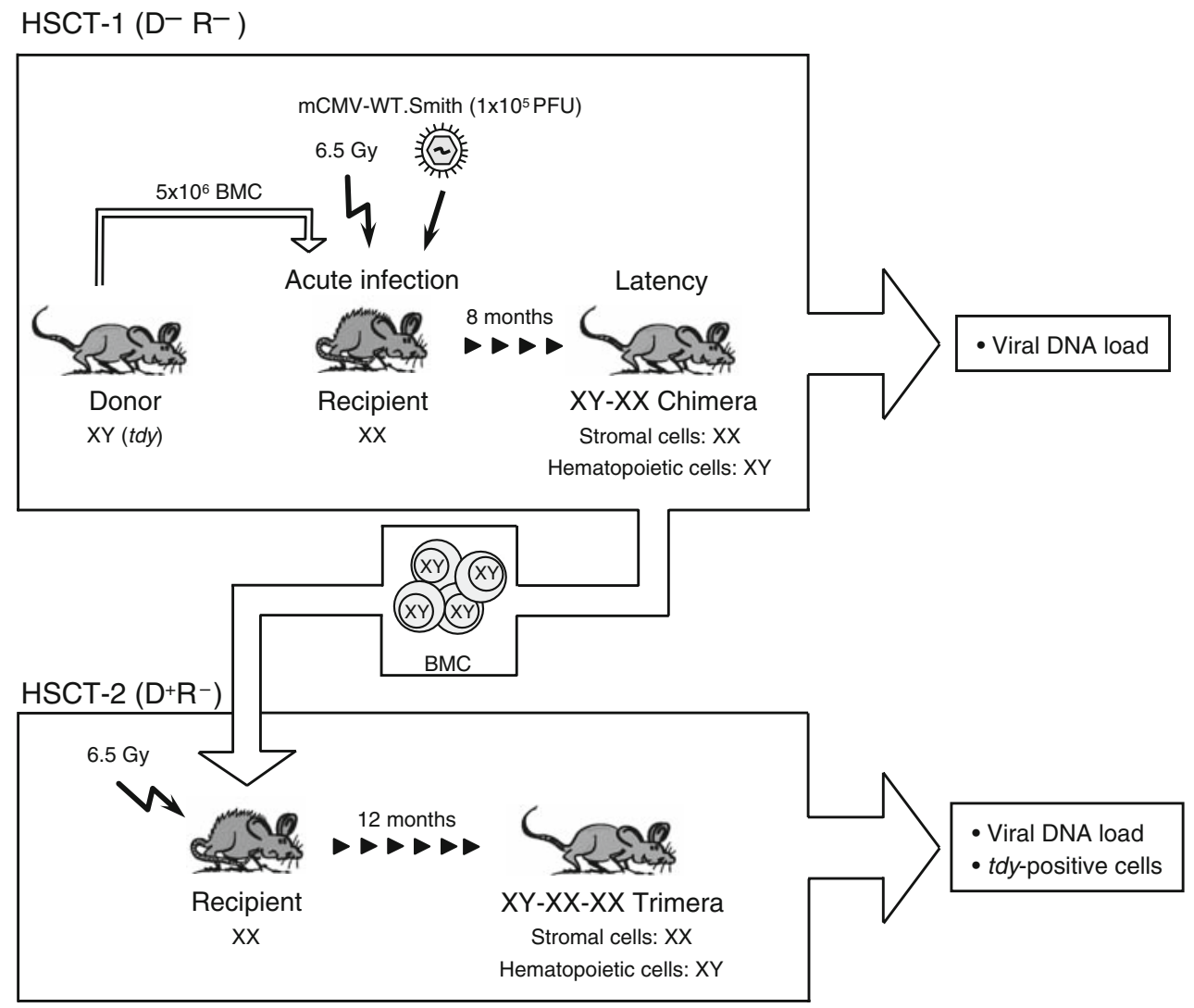

Fig. 1 Experimental regimen and time course of serial HSCT. Schema illustrating the approach of serial hematopoietic stem cell transplantation (serial HSCT) in the murine model of CMV latency in the bone marrow. (top panel, HSCT-1) Sex-mismatched HSCT was performed with $5 \times 10^{6}$ femoral and tibial bone marrow cells (BMC) from male BALB/c donor mice carrying the $t d y$ gene on the $\mathrm{Y}$ chromosome (XY genotype). HSCT-1 corresponds to a $\mathrm{D}^{-} \mathrm{R}^{-}$pre-transplantation $\mathrm{CMV}$-serostatus of donor and recipient with extraneous primary infection. Upon intravenous transplantation into $\gamma$-irradiated (flash symbol $6.5 \mathrm{~Gy}$ ) female BALB/c recipients (XX genotype), male donor hematopoietic cells replace the radiation-sensitive female hematopoietic cells, whereas the radiation-resistant female stromal cells are not replaced, which leads to $\mathrm{XY}-\mathrm{XX}$ bone marrow chimeras. On the day of HSCT-1, recipients were infected with $1 \times 10^{5} \mathrm{PFU}$ of mCMV-

low-level persistence of productive infection of HSCT-2 donors, that is the HSCT-1 recipients. In addition, to make sure that viral genomes detected in BMC originated from the hematopoietic and/or stromal compartment of the bone marrow but not from the vascular compartment, in this model we defined latency as a state at which viral genomes are detectable in organs but are absent from peripheral blood [39-41] (for a review see [25]). The conclusion from the previous findings was that viral DNA present in blood leukocytes, in $\mathrm{Gr}-1^{+} \mathrm{CD} 11 \mathrm{~b}^{+}$granulocytes in particular, results from the acute organ infection by virus uptake rather than from exported latently infected hematopoietic cell progeny [42] and that clearance of productive infection in host organs, including the salivary glands as the privileged site of prolonged virus replication (see the contribution by
WT.Smith. At 8 months after this primary infection, the meanwhile latently infected $\mathrm{XY}-\mathrm{XX}$ chimeras served as BMC donors for a further HSCT. The number of transplanted latent virus genomes was determined by real-time PCR. HSCT-2 (bottom panel, HSCT-2) corresponds to a $\mathrm{D}^{+} \mathrm{R}^{-}$pre-transplantation CMV-serostatus of donor and recipient, a constellation that bears a risk of virus reactivation from donor cells only. HSCT-2 was performed as a "one-into-one" transplantation, that is the total yield of BMC (except 10\% required for viral load determination) from one chimeric donor was transferred into one female recipient, thus leading to $\mathrm{XY}-\mathrm{XX}-\mathrm{XX}$ trimeras. Viral DNA loads in lungs, liver, spleen, and bone marrow as well as the proportion of donor-derived hematopoietic cells were determined by the respective real-time PCRs at 12 months after HSCT-2

Campbell et al. in this issue of MMI), precedes clearance of viral DNA from the blood by $\sim 4$ months [41].

To take all this into account, HSCT-1 recipients were monitored for the time course of virus replication in organs of experimental group members by a highly sensitive PFU assay [41] as well as longitudinally in individual mice for the clearance of viral genomes from the tail vein blood. In accordance with previous data [41], productive infection was found to be cleared in all organs at 6 months after infection (data not shown) and, in this experiment, at 8 months viral DNA was cleared from the blood in all individual mice tested, with a single exception (Fig. 2). Five of the chimeric HSCT-1 recipients that had already cleared viral genome from the blood were selected to serve as latently infected donors in HSCT-2. 


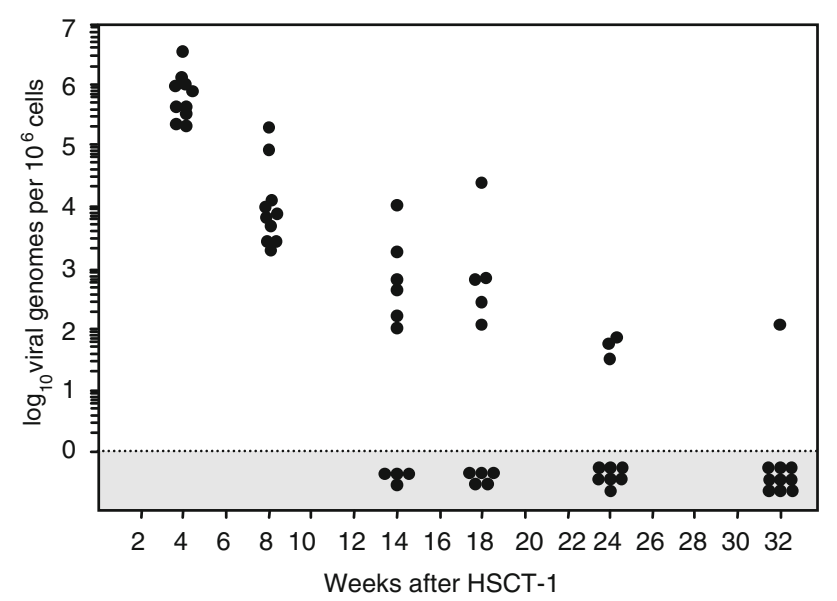

Fig. 2 Kinetics of viral DNA clearance from blood after HSCT-1. Longitudinal analysis of viral DNA load in tail vein blood of 10 individual HSCT-1 recipients by $M 55 / g B$-specific real-time PCR. Closed circles represent data for individual mice at weeks $4,8,14,18,24$, and 32 after HSCT-1. The grey-shaded zone indicates absence of detectable viral DNA

Quantitation of viral DNA in the bone marrow of individual HSCT-2 donors at the time of transplantation to individually corresponding HSCT-2 recipients (one-into-one HSCT) was performed for a $10 \%$ aliquot of the BMC by real-time PCR (Fig. 3) and the data were extrapolated to the $90 \%$ of the BMC that were transferred to HSCT-2 recipients (Table 1). Thus estimated numbers of transferred viral genomes were fairly low, ranging from undetectable to $\sim 2,500$ genomes. The highest amount of latent genomes transferred (HSCT-2 donor and recipient pair \#4) corresponds to just $5 \mathrm{PFU}$ in acute infection, based on a genometo-infectivity ratio of $\sim 500$ [41]. That the HSCT-2 donors were indeed latently infected is documented for the very same individual mice by a quite high latent viral genome load in the organs tested (Fig. 4). For instance, donor \#2 was found to carry only $\sim 5$ latent viral genomes per $10^{6}$ BMC (Table 1), whereas the load was $\sim 7,500$ latent viral genomes per $10^{6}$ lung cells, $\sim 450$ per $10^{6}$ liver cells, and $\sim 2,500$ per $10^{6}$ spleen cells. Calculations for the other four donors gave comparable results, with no obvious correlation between latent viral DNA load in BMC and in organs.

In conclusion, although latent viral DNA can be found in low copy numbers in BMC, these data clearly indicate that the bone marrow is, at best, a very minor site of mCMV latency. In accordance with previous work [39], recipient organs, the lungs in particular, are here confirmed as being the major source of latent viral genomes. Whether hematopoietic cells carry latent viral DNA at all is still unclear. Previous work has shown that under conditions of CMVmediated bone marrow aplasia reticular bone marrow stromal cells are infected in vivo with features of a non-productive "latent" infection characterized by limited viral

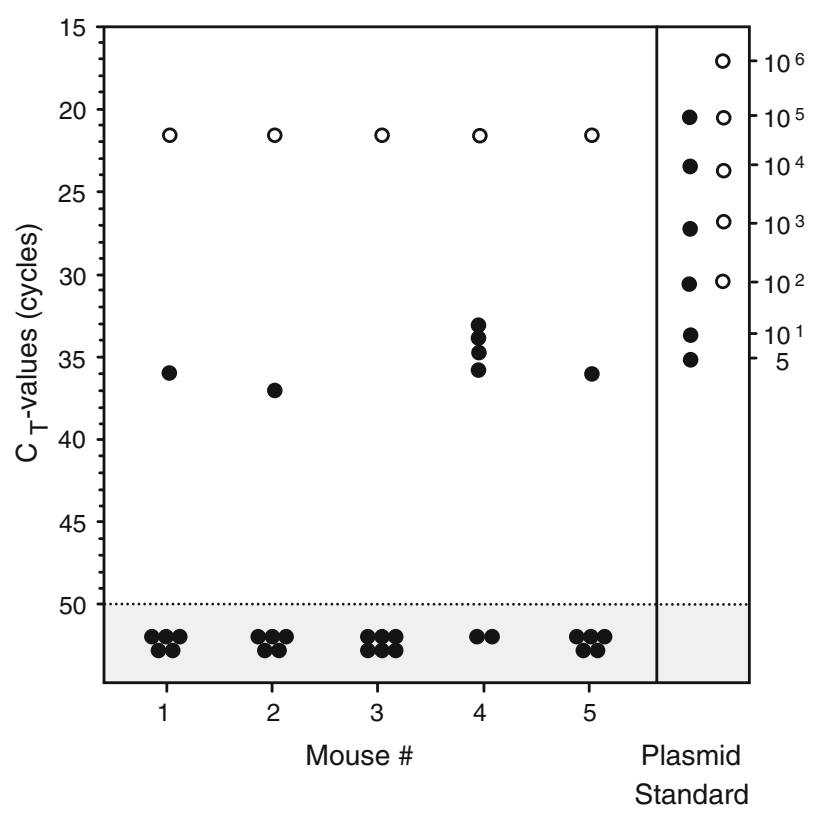

Fig. 3 Viral DNA load in BMC derived from latently infected HSCT1 recipients. Viral genomes were quantitated in BMC derived from five latently infected HSCT-1 recipients (mouse \#1 through mouse \#5) at 8 months after HSCT and primary infection. Real-time PCR specific for the viral gene $M 55 / g B$ was performed individually for the five recipients in six replicates representing 6 out of 50 aliquots of the DNA isolated from $10 \%$ of the respective BMC yields (see also Table 1). Closed circles represent the numbers of viral sequence amplification cycles (cycle threshold $\left[\mathrm{C}_{\mathrm{T}}\right]$ values), and open circles represent the numbers of cellular gene (pthrp) amplification cycles required for detection. The dotted line marks the cutoff value of 50 amplification cycles defined by the water control. The grey-shaded zone indicates absence of detectable viral DNA. Separated by the solid line, closed and open circles represent standard titrations for viral and cellular sequences, respectively, performed with graded numbers of plasmid pDrive_gB_PTHrP_Tdy [32] that comprises both the viral and the cellular gene. $10^{2}$ plasmids were measured in duplicates, 10 and 5 plasmids were measured in triplicates. Depicted are only the mean values. Note that 35 amplification cycles correspond to 5 viral templates in the probe. As probes which are below the cutoff value may nevertheless contain 1 or 2 viral templates, the sum of viral genomes calculated from the positive replicates for each of the 5 mice represents a minimum estimate of the number of viral genomes present in 6 out of 50 DNA aliquots (see above as well as Table 1)

gene expression associated, however, with an altered expression of cellular hemopoietin genes [29, 30]. In HSCT chimeras, the stromal network is always recipient-derived, as stromal cells, even if they are present in the donor BMC population, are not transplantable [29, 30]. Thus, the low number of latent viral genomes detected in BMC might reside in stromal cells rather than in hematopoietic cells. As the stroma is the tissue of the bone marrow, latent infection of the stroma would be in compliance with latent infection in most other tissues, and the low viral genome load in bone marrow might simply reflect the low proportion of stromal cells among the BMC that are quantitatively dominated by hematopoietic cells [29] (see also Fig. 5a). 
Table 1 Viral DNA load in the bone marrow of HSCT-1 recipients

$D L$ detection limit

\begin{tabular}{|c|c|c|c|c|c|c|c|}
\hline \multirow[t]{2}{*}{ Mouse \# } & \multirow{2}{*}{$\begin{array}{l}\text { Yield } \\
\text { of BMC }\end{array}$} & \multirow{2}{*}{$\begin{array}{l}\text { Transplanted } \\
\text { BMC }\end{array}$} & \multirow{2}{*}{$\begin{array}{l}\text { BMC for viral } \\
\text { DNA load }\end{array}$} & \multicolumn{4}{|c|}{ Minimum estimate of viral genomes per } \\
\hline & & & & $\begin{array}{l}6 \text { of } 50 \\
\text { aliquots }\end{array}$ & $\begin{array}{l}50 \text { of } 50 \\
\text { aliquots }\end{array}$ & $\begin{array}{l}\text { BMC } \\
\text { transplanted }\end{array}$ & $10^{6} \mathrm{BMC}$ \\
\hline 1 & $3.8 \times 10^{7}$ & $3.4 \times 10^{7}$ & $3.8 \times 10^{6}$ & 4 & 33 & 297 & 8.7 \\
\hline 2 & $3.3 \times 10^{7}$ & $3.0 \times 10^{7}$ & $3.3 \times 10^{6}$ & 2 & 17 & 153 & 5.1 \\
\hline 3 & $4.4 \times 10^{7}$ & $4.0 \times 10^{7}$ & $4.4 \times 10^{6}$ & $<\mathrm{DL}$ & - & - & - \\
\hline 4 & $3.2 \times 10^{7}$ & $2.9 \times 10^{7}$ & $3.2 \times 10^{6}$ & 34 & 283 & 2,547 & 87.8 \\
\hline 5 & $3.3 \times 10^{7}$ & $3.0 \times 10^{7}$ & $3.3 \times 10^{6}$ & 3 & 25 & 225 & 7.5 \\
\hline
\end{tabular}
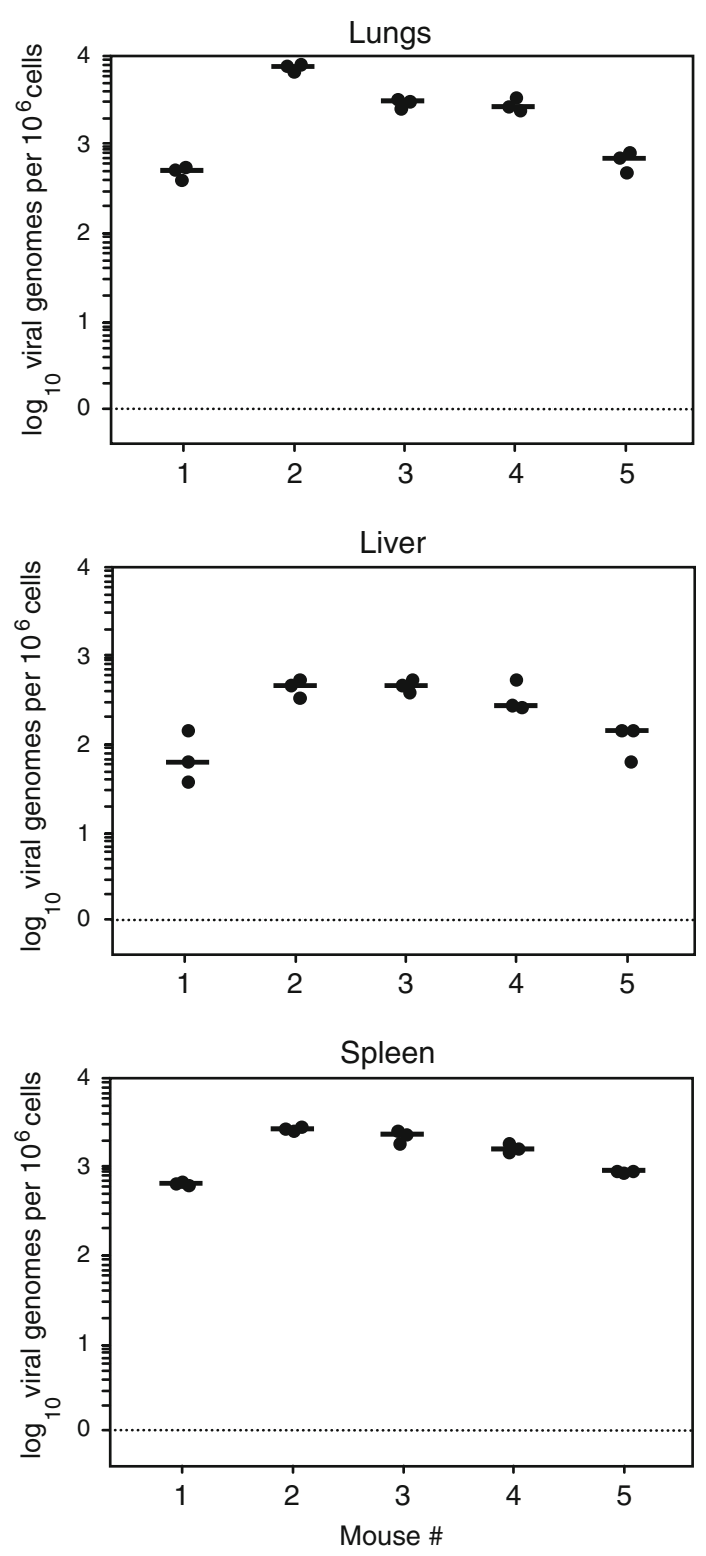

Fig. 4 Viral DNA load in latently infected HSCT-1 recipients. Viral genomes in lungs, liver, and spleen of the five latently infected bone marrow chimeras were quantitated at 8 months after HSCT-1. Closed circles represent triplicate DNA preparation samples measured by $M 55 / g B$-specific real-time PCR. Median values are indicated
Viral latency is not transplantable by HSCT

Although the latent viral DNA load was very low in the BMC of the HSCT-2 donors, there still existed the possibility that a few latent viral genomes, if present in hematopoietic stem or early progenitor cells, might be multiplied in the HSCT recipients as the hematopoietic cells engraft, proliferate, and differentiate. In addition, virus reactivation in latently infected transplanted cells or in their more differentiated progeny could lead to a primary productive infection of the recipients, which would be reflected by a massive increase in the viral DNA load. To test for this, a 1-year follow-up was made for the five HSCT-2 recipients by measuring the viral DNA load in tail vein blood in weekly intervals for 2 months and in bimonthly intervals thereafter. At no time could viral DNA be detected in tail vein blood and none of the HSCT-2 recipients ever developed signs of CMV disease (data not shown). Thus, there was no evidence whatsoever for a primary infection of the immunocompromised and therefore, highly susceptible HSCT recipients in this experimental $\mathrm{D}^{+} \mathrm{R}^{-}$setting of HSCT. Finally, after 12 months, viral DNA load was determined in $\mathrm{BMC}$ and in various organs.

The disenchanting result is shown in Fig. 5. Whereas male ( $t d y$ gene-positive) hematopoietic cells, derived from the HSCT-1 donors 20 months earlier, were found to have repopulated the bone marrow of the XY-XX-XX HSCT-2 recipients (Fig. 5a, left column) and male progeny were present in an organotypic distribution (Fig. 5b, left column), viral genomes were absent throughout (Fig. 5a, b; right column).

\section{Concluding remarks and outlook}

In essence, we have shown that BMC from latently infected HSCT donors do not transmit virus to recipients in a murine model of MHC-matched, sex-mismatched allo-HSCT with $\mathrm{D}^{+} \mathrm{R}^{-} \mathrm{CMV}$ status.

Sure, in view of the literature on hCMV latency in cells of the myeloid lineage one can argue that a murine model 

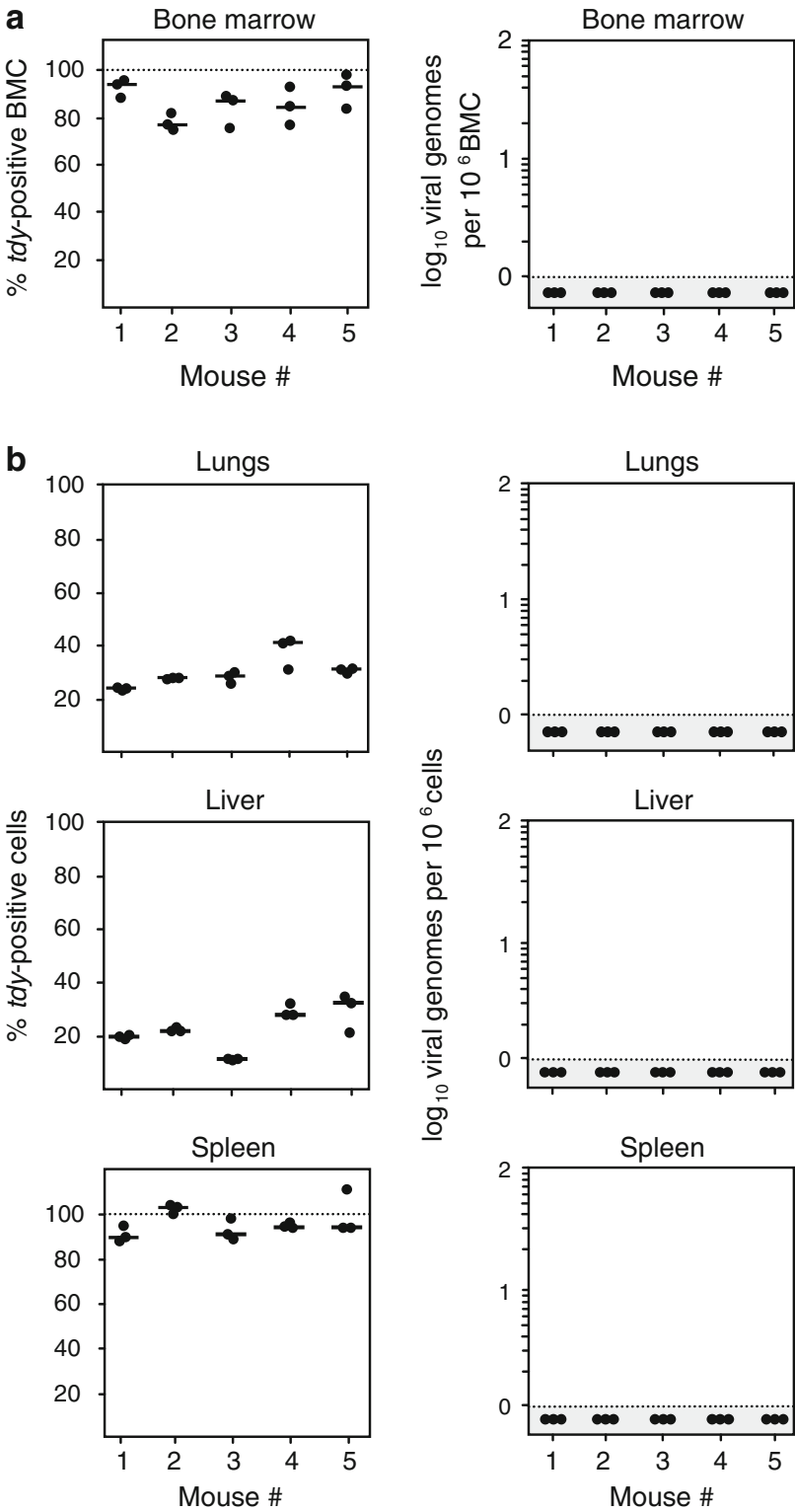

Fig. 5 Proportion of donor-derived $t d y$-positive cells and latent viral DNA load in HSCT-2 recipients. Donor-derived $t d y$-positive cells (left column) and latent viral genomes (right column) were quantitated by the respective real-time PCRs at 12 months after HSCT- 2 a in bone marrow cells (BMC) and $\mathbf{b}$ in lungs, liver, and spleen of the five trimeric recipients. Closed circles represent PCR data for triplicate DNA preparation samples. Median values for the percentages of $t d y$-positive cells are marked. The grey-shaded zone indicates absence of detectable viral DNA

based on fibroblast-propagated mCMV-WT.Smith may not adaequately represent the clinical situation after infection with myelotropic variants of hCMV. This is certainly true. On the other hand, however, different clinical isolates of hCMV differ significantly from each other in their cell type tropism $[21,22,43]$. Therefore, regarding the establishment of latency in hematopoietic cells and the transmission of latent viral DNA by clinical HSCT, there exists no uniform answer either. Interestingly, mCMV replication is less cell-type restricted than is the replication of many hCMV isolates. In immunocompromised mice, mCMV-WT.Smith and bacterial artificial chromosome (BAC)-cloned mCMV-WT.BAC [44] replicate in many cell types, including fibrocyte-like stromal cells, many different types of epithelial cells, endothelial cells, macrophages, and dendritic cells [35]. Even an enhancer swap mutant of mCMV that carries the hCMV major immediate-early promoter-enhancer [45] (see also the contribution by Stinski and Isomura in this issue of MMI) replicated in vivo in essentially all kinds of tissues [45]. In long-term bone marrow cell cultures, however, the myelosuppressive effect of mCMV-WT.Smith could be attributed to the infection of bone marrow stroma, whereas the hematopoietic myeloid-lineage progenitor cells were not directly targeted and could thus be rescued from infected cell cultures by transfer to uninfected stromal cell monolayers [46]. Although this is a distinctive feature by which mCMV-WT.Smith and some clinical isolates/variants of hCMV differ, the majority of the isolates were found to behave like mCMV-WT.Smith in this particular respect $[21,46]$. Thus, the murine model may be valid for some but not all clinical isolates or low-passage strains of hCMV.

Nonetheless, with respect to the low risk of symptomatic infection of recipients in HSCT with a $\mathrm{D}^{+} \mathrm{R}^{-} \mathrm{CMV}$ status [23] (see above), the murine model strikingly mirrors the clinical risk assessment. This is probably the strongest argument for the validity of the murine model, at least with regard to the majority of hCMV variants.

Previous studies in different murine models, including neonatal infection and infection in HSCT, have clearly documented a correlation between latent viral DNA load and the risk of virus reactivation and recurrence [39, 47, 48]. From the very low load of latent viral DNA in bone marrow, in particular when compared with the high load in organs, as described here for the murine HSCT model, we would conclude that it is primarily the latent viral DNA load that defines the probability for virus reactivation in $\mathrm{D}^{+} \mathrm{R}^{-}$settings, which would explain why a $\mathrm{D}^{+} \mathrm{R}^{-} \mathrm{CMV}$ status predicts low and high risk for HSCT and solid organ transplantations, respectively [23].

There exists, however, an alternative explanation. In a $\mathrm{D}^{+} \mathrm{R}^{+}$setting, the risk should be additive due to latent CMV DNA load contributed by both donor and recipient; however, the clinical data showed that in HSCT the risk in a $\mathrm{D}^{+} \mathrm{R}^{+}$setting is lower than in a $\mathrm{D}^{-} \mathrm{R}^{+}$setting, a finding that may indicate that pre-existing donor immunity controls virus reactivation in the recipient unless cells involved in adaptive immunity are depleted prior to HSCT. This hypothesis can now be experimentally tested in the murine model of HSCT and CMV infection. 
Acknowledgments This work was supported by the Deutsche Forschungsgemeinschaft, SFB 490, individual project E2 "Immunological control of latent cytomegalovirus infection" (all authors) and Clinical Research Group KFO 183, individual project TP8 "Establishment of a challenge model to optimize the immunotherapy of cytomegalovirus diseases" (M.J.R.). Special thanks go to the "Dr. Hans-Joachim und Ilse Brede-Stiftung" for a generous donation.

\section{References}

1. Appelbaum FR (2003) The current status of hematopoietic cell transplantation. Annu Rev Med 54:491-512

2. Kolb HJ, Schmid C, Barrett AJ, Schendel DJ (2004) Graft-versusleukemia reactions in allogeneic chimeras. Blood 103:767-776

3. Hebart H, Einsele H (2004) Clinical aspects of CMV infection after stem cell transplantation. Hum Immunol 65:432-436

4. Riddell SR (1995) Pathogenesis of cytomegalovirus pneumonia in immunocompromised hosts. Semin Respir Infect 10:199-208

5. Wills MR, Carmichael AJ, Patrick Sissons JG (2006) Adaptive cellular immunity to human cytomegalovirus. In: Reddehase MJ (ed) Cytomegaloviruses: molecular biology and immunology. Caister Academic Press, Norfolk, pp 341-365

6. Maciejewski JP, Bruening EE, Donahue RE, Mocarski ES, Young NS, St Jeor SC (1992) Infection of hematopoietic progenitor cells by human cytomegalovirus. Blood 80:170-178

7. Mendelson M, Monard S, Sissons P, Sinclair J (1996) Detection of endogenous cytomegalovirus in $\mathrm{CD} 34^{+}$bone marrow progenitors. J Gen Virol 77:3099-3102

8. Söderberg-Nauclér C, Fish KN, Nelson JA (1997) Reactivation of latent human cytomegalovirus by allogeneic stimulation of blood cells from healthy donors. Cell 91:119-126

9. Hahn G, Jores R, Mocarski ES (1998) Cytomegalovirus remains latent in a common precursor of dendritic and myeloid cells. Proc Natl Acad Sci USA 95:3937-3942

10. Bolovan-Fritts CA, Mocarski ES, Wiedeman JA (1999) Peripheral blood $\mathrm{CD} 14^{+}$cells from healthy subjects carry a circular conformation of latent cytomegalovirus genome. Blood 93:394-398

11. Slobedman B, Mocarski ES (1999) Quantitative analysis of latent human cytomegalovirus. J Virol 73:4806-4812

12. Goodrum FD, Jordan CT, High K, Shenk T (2002) Human cytomegalovirus gene expression during infection of primary hematopoietic progenitor cells: a model for latency. Proc Natl Acad Sci USA 99:16255-16260

13. Goodrum F, Jordan CT, Terhune SS, High K, Shenk T (2004) Differential outcomes of human cytomegalovirus infection in primitive hematopoietic cell subpopulations. Blood 104:687-695

14. Reeves MB, MacAry PA, Lehner PJ, Sissons JG, Sinclair JH (2005) Latency, chromatin remodeling, and reactivation of human cytomegalovirus in the dendritic cells of healthy carriers. Proc Natl Acad Sci USA 102:4140-4145

15. Goodrum F, Reeves M, Sinclair J, High K, Shenk T (2007) Human cytomegalovirus sequences expressed in latently infected individuals promote a latent infection in vitro. Blood 110:937-945

16. Jarvis MA, Nelson JA (2002) Human cytomegalovirus persistence and latency in endothelial cells and macrophages. Curr Opin Microbiol 5:403-407

17. Streblow DN, Nelson JA (2003) Models of HCMV latency and reactivation. Trends Microbiol 11:293-295

18. Sinclair J, Sissons P (2006) Latency and reactivation of human cytomegalovirus. J Gen Virol 87:1763-1779

19. Bain M, Reeves M, Sinclair J (2006) Regulation of human cytomegalovirus gene expression by chromatin remodelling. In: Reddehase MJ (ed) Cytomegaloviruses: molecular biology and immunology. Caister Academic Press, Norfolk, pp 167-183
20. Reeves M, Sinclair J (2008) Aspects of human cytomegalovirus latency and reactivation. In: Shenk TE, Stinski MF (eds) Human cytomegalovirus. Current topics in microbiology and immunology, vol 325. Springer, Heidelberg, pp 297-314

21. Simmons P, Kaushansky K, Torok-Storb B (1990) Mechanisms of cytomegalovirus-mediated myelosuppression: perturbation of stromal cell function versus direct infection of myeloid cells. Proc Natl Acad Sci USA 87:1386-1390

22. Shenk T (2006) Human cytomegalovirus genomics. In: Reddehase MJ (ed) Cytomegaloviruses: molecular biology and immunology. Caister Academic Press, Norfolk, pp 49-61

23. Emery VC (1998) Relative importance of cytomegalovirus load as a risk factor for cytomegalovirus disease in the immunocompromised host. In: Scholz M, Rabenau HF, Doerr HW, Cinatl J Jr (eds) Monographs in virology 21: CMV-related immunopathology. Karger, Basel, pp 288-301

24. Grundy JE, Lui SF, Super M, Berry NJ, Sweny P, Fernando ON, Moorhead J, Griffiths PD (1988) Symptomatic cytomegalovirus infection in seropositive kidney recipients: reinfection with donor virus rather than reactivation of recipient virus. Lancet 16:132-135

25. Reddehase MJ, Podlech J, Grzimek NK (2002) Mouse models of cytomegalovirus: overview. J Clin Virol 25:S23-S36

26. Hummel M, Abecassis MM (2002) A model for reactivation of CMV from latency. J Clin Virol 25:S123-S136

27. Simon CO, Seckert CK, Grzimek NKA, Reddehase MJ (2006) Murine model of cytomegalovirus latency and reactivation: the silencing/desilencing and immune sensing hypothesis. In: Reddehase MJ (ed) Cytomegaloviruses: molecular biology and immunology. Caister Academic Press, Norfolk, pp 483-500

28. Reddehase MJ, Simon CO, Seckert CK, Lemmermann N, Grzimek NKA (2008) Murine model of cytomegalovirus latency and reactivation. In: Shenk TE, Stinski MF (eds) Human cytomegalovirus. Current topics in microbiology and immunology, vol 325. Springer, Heidelberg, pp 315-332

29. Mayer A, Podlech J, Kurz S, Steffens HP, Maiberger S, Thalmeier K, Angele P, Dreher L, Reddehase MJ (1997) Bone marrow failure by cytomegalovirus is associated with an in vivo deficiency in the expression of essential stromal hemopoietin genes. J Virol 71:4589-4598

30. Steffens HP, Podlech J, Kurz S, Angele P, Dreis D, Reddehase MJ (1998) Cytomegalovirus inhibits the engraftment of donor bone marrow cells by downregulation of hemopoietin gene expression in recipient stroma. J Virol 72:5006-5015

31. Podlech J, Holtappels R, Grzimek NKA, Reddehase MJ (2002) Animal models: murine cytomegalovirus. In: Kaufmann SHE, Kabelitz D (eds) Methods in microbiology 32. Immunology of infection. Academic Press, San Diego, pp 493-525

32. Simon CO, Seckert CK, Dreis D, Reddehase MJ, Grzimek NK (2002) Role for tumor necrosis alpha in murine cytomegalovirus transcriptional reactivation in latently infected lungs. J Virol 79:326-340

33. Dobonici M, Podlech J, Steffens HP, Maiberger S, Reddehase MJ (1998) Evidence against a key role for transforming growth factorbeta1 in cytomegalovirus-induced bone marrow aplasia. J Gen Virol 79:867-876

34. Holtappels R, Podlech J, Geginat G, Steffens HP, Thomas D, Reddehase MJ (1998) Control of murine cytomegalovirus in the lungs: relative but not absolute immunodominance of the immediate-early 1 nonapeptide during the antiviral cytolytic T-lymphocyte response in pulmonary infiltrates. J Virol 72:7201-7212

35. Podlech J, Holtappels R, Wirtz N, Steffens HP, Reddehase MJ (1998) Reconstitution of CD8 T cells is essential for the prevention of multiple-organ cytomegalovirus histopathology after bone marrow transplantation. J Gen Virol 79:2099-2104

36. Podlech J, Holtappels R, Pahl-Seibert M-F, Steffens HP, Reddehase MJ (2000) Murine model of interstitial cytomegalovirus pneu- 
monia in syngeneic bone marrow transplantation: persistence of protective pulmonary CD8-T-cell infiltrates after clearance of acute infection. J Virol 74:7496-7507

37. Simon CO, Holtappels R, Tervo HM, Böhm V, Däubner T, Oehrlein-Karpi SA, Kühnapfel B, Renzaho A, Strand D, Podlech J, Reddehase MJ, Grzimek NK (2006) CD8 T cells control cytomegalovirus latency by epitope-specific sensing of transcriptional reactivation. J Virol 80:10436-10456

38. Holtappels R, Munks MW, Podlech J, Reddehase MJ (2006) CD8 T-cell-based immunotherapy of cytomegalovirus disease in the mouse model of the immunocompromised bone marrow transplantation recipient. In: Reddehase MJ (ed) Cytomegaloviruses: molecular biology and immunology. Caister Academic Press, Norfolk, pp 383-418

39. Balthesen M, Messerle M, Reddehase MJ (1993) Lungs are a major organ site of cytomegalovirus latency and recurrence. J Virol 67:5360-5366

40. Balthesen M, Dreher L, Lučin P, Reddehase MJ (1994) The establishment of cytomegalovirus latency in organs is not linked to local virus production during primary infection. J Gen Virol 75:2329-2336

41. Kurz S, Steffens HP, Mayer A, Harris JR, Reddehase MJ (1997) Latency versus persistence or intermittent recurrences: evidence for a latent state of murine cytomegalovirus in the lungs. J Virol 71:2980-2987

42. Balthesen M, Šša M, Lučin P, Reddehase MJ (1994) Cytomegalovirus DNA detected in blood leukocytes after resolution of productive infection does not originate from latently infected hematopoietic stem cells in the bone marrow. Croat Med J 35:1925

43. Digel M, Sinzger C (2006) Determinants of endothelial cell tropism of human cytomegalovirus. In: Reddehase MJ (ed) Cytomegaloviruses: molecular biology and immunology. Caister Academic Press, Norfolk, pp 445-464

44. Wagner M, Jonjić S, Koszinowski UH, Messerle M (1999) Systematic excision of vector sequences from the BAC-cloned herpesvirus genome during virus reconstitution. J Virol 73:70567060

45. Grzimek NK, Podlech J, Steffens HP, Holtappels R, Schmalz S, Reddehase MJ (1999) In vivo replication of recombinant murine cytomegalovirus driven by the paralogous major immediate-early promoter-enhancer of human cytomegalovirus. J Virol 73:50435055

46. Busch FW, Mutter W, Koszinowski UH, Reddehase MJ (1991) Rescue of myeloid lineage-committed preprogenitor cells from cytomegalovirus-infected bone marrow stroma. J Virol 65:981984

47. Reddehase MJ, Balthesen M, Rapp M, Jonjić S, Pavić I, Koszinowski UH (1994) The conditions of primary infection define the load of latent viral genome in organs and the risk of recurrent cytomegalovirus disease. J Exp Med 179:185-193

48. Steffens HP, Kurz S, Holtappels R, Reddehase MJ (1998) Preemptive CD8 T-cell immunotherapy of acute cytomegalovirus infection prevents lethal disease, limits the burden of latent viral genomes, and reduces the risk of virus recurrence. J Virol 72:1797-1804 